\title{
Toksoplazmoz Tanısı
}

\author{
Diagnosis Of Toxoplasmosis
}

Gülay Aral Akarsu

Toksoplazmoz, Apikompleksan bir protozoon olan Toxoplasma gondii'nin etken olduğu bir paraziter hastalıktır. İmmunkompetan kişilerde çoğunlukla asemptomatik, kendini sınırlayan nezle benzeri bir tablo veya lokal lenfadenopati ile seyrederken; immun yetmezliği olanlarda ve enfekte fetus veya yenidoğanlarda ölümle sonuçlanabilen ağır tablolara yol açabilmektedir. Histolojik tanı veya organizmanın izolasyonu zor ve zaman alıcı olduğu için, tanıda esas olarak serolojik tanı yöntemleri kullanılmaktadır. Bu derlemede, toksoplazmoz tanısında değişik hasta gruplarında kullanılabilecek antikor tipleri ve serolojik yöntemler gözden geçirilmiştir. Özellikle toksoplazmoz tanısının önemli ama zor olduğu gebeler ve yeni doğanlarda öne çıkan bazı yeni ve geliştirilmiş tanı yöntemlerinden bahsedilmiş ve serolojik testlerin yorumlanmasında karşılaşılabilecek sorunlar özetlenmiştir.

Anahtar Kelimeler: Toxoplasma gondii, tanı, seroloji, gebelik, immunkompromize

Toxoplasmosis is a parasitic disease caused by the Apicomplexan protozoan Toxoplasma gondii. Toxoplasmosis is generally asymptomatic or characterized either with regional lymphadenopathy or a flu-like illness in immunocompetant patients. On the other hand, it can have deleterious effects with fetal consequences on fetuses, newborns and immunocompromised patients. As histological diagnosis and isolation from tissues is labor-intensive, time-consuming and less sensitive than indirect diagnostic methods, serology became the main diagnostic choice in toxoplasmosis. Antibody types and different serological methods which are suitable for the diagnosis of toxoplasmosis in different patient groups were reviewed. Some new and improved immunological techniques used for the detection of toxoplasmosis in pregnant women and newborns were summarized and the problems due to the difficulty of interpretation of serological results were discussed.

Key Words: Toxoplasma gondii, diagnosis, serology, pregnancy, immunocompromise

Toxoplasma gondii, ilk defa Pasteur Enstitüsü'nde Charles Nicolle ve Louis Manceaux tarafindan 1908 yılında Tunus'ta, Kuzey Afrikalı bir kemirgen olan Ctenodactylus gundi'den izole edilerek tanımlanmiştır. (1). Bununla birlikte yaşam döngüsü tam olarak 1970'lere kadar belirlenmemistir. İlk konjenital insan vakası, göz hekimi Janko tarafından 1923'te, ilk erişkin vaka ise 1940'ta tanınmıştır. Toxoplasma klinik öneminin yanısıra son zamanlarda Apikompleksan parazitlerin biyokimyası, biyolojisi ve genetiği ile ilgili çalışmalarda da model olarak kullanılmaktadır (2).
İnsanlarda $T$. gondii, iki değişik formda bulunmaktadır. Aktif olarak prolifere olan hücre içi formlar, virgül şeklinde olup, takizoit ismini almakta ve hemen tüm çekirdekli hücreleri enfekte edebildikleri için akciğer, kalp, lenfoid organlar ve santral sinir sistemini de içeren yaygın bir yerleşim göstermektedirler. Doku kisti formları ise parazitofor vakuol içinde takizoitlerden daha yavaş çoğalan bradizoitlerdir. T. gondii'nin üçüncü formu olan ookistler son konak olan kedinin barsağında gelişmekte ve dişkısı ile dış ortama atıldıktan sonra sporule olarak insan için enfektif hale gelmektedir (3). 
Parazitin uyardığı konak hücre harabiyeti sonucu oluşan patoloji, enfekte eden parazitin virülans1na bağlıdır. T. gondii'nin, \%1 civarında genetik farklılık gösteren ama belirgin fenotipik farklılıkları bulunan 3 ayrı klonal ırkı (lineage) tanımlanmıştır: Tip I, sık görülmeyen ve farelerde en virülan olan irk; tip II, insanlarda en sık enfeksiyona yol açan ama daha az virülan olan 1rk ve tip III, sık görülmeyen ve fenotipik olarak değişken 1rk (4). T. gondii, memeli, kuş ve sürüngenleri içeren geniş bir canlı grubunu enfekte edebilmektedir. Doğada kemirgenler ve küçük kuşlar önemli rezervuarlardır. Enfeksiyon, Felidae ailesinin üyelerinin dışkılarıyla yayılan ookistlerin, genellikle, kontamine su veya yiyecekler yoluyla ağıdan alınması ile; çiğ veya az pişmiş etlerdeki bradizoit formunu barındiran doku kistlerinden; organ transplantasyonu, transfüzyonlar veya transplasental geçiş ile bulaşabilir. İnsan enfeksiyonunda en çok görülen bulaş, doku kisti içeren çiğ veya az pişmiş etler aracılığı ile gerçekleşmektedir (5). Dünya nüfusunun ortalama olarak \%30-65'inin Toxoplasma ile enfekte olduğu tahmin edilmektedir. Prevalans, Fransa, Almanya, Hollanda'da \%80 civarında iken, Ingiltere'de \%22 ve Güney Kore'de sadece \%4.2'dir. Ülkemizde, çoğunlukla öntanılı vakalardan yapılan çalışmalarda IgG seropozitifliği araştırılmış ve \%23.1 ile \%57.6 olarak bildirilmiştir. Altıntaş ve arkadaşlarının 1998 y1lında İzmir çevresindeki yerleşim bölgelerinde yaşayan 1865 kişi ile yaptıkları araştırma, bölgesel olmakla beraber bu anlamda yapılan çalışmaların en kapsamlılarından olup seropozitiflik \%23.1 olarak bildirilmiştir (6).

\section{Klinik}

Toksoplazmoz, immunkompetan kişilerde \%90 asemptomatik, \%10 ise hafif, kendini sınırlayan semptom ve bulgularla (ağrısız servikal lenfadenopati, nezle benzeri tablo gibi) seyretmektedir. Konjenital enfeksiyonlarda ve immunkompromize hastalarda ise ölümcül hastalığa kadar ilerleyebilmektedir. Akut fazdan sonra parazit, merkezi sinir sistemi ve kas dokusu gibi dokularda bradizoitler içeren yalancı kistler olarak kalabilmekte ve altta yatan bir neden olduğunda reaktivasyon gösterebilmektedir.

Enfeksiyon, immunkompromize hastalarda (maligniteler, kollajen vasküler hastalıklar, organ transplantasyonları ve AIDS) en sik, diffüz ensefalopati, meningoensefalit veya beyinde yer tutan lezyonla karakterize sinir sistemi tutulumu ile kendini göstermektedir (7). AIDS hastalarında insan ve hayvan enfeksiyonlarında sık görülmeyen tip I suşu ile enfeksiyon daha sıktır. T. gondii ve HIV-1 karş1lıklı olarak birbirlerinin replikasyonunu arttırmaktadır. Steroid veya diğer immunsupresif ilaçlar alan hastalar, organizma ile akut karşılaşma ya da latent enfeksiyonun reaktivasyonu sonucu yaygin toksoplazmoz geliştirme eğilimindedirler.

Transplantasyon hastalarında hastal1ğın şiddeti, donör ve alıcının daha önceden $T$. gondii ile karşılaşıp karşılaşmamasına, transplante edilen organa, immunsupresyonun miktarına göre değişebilmektedir (8). Transplant alıcıları, antikor durumlarının anlaşılması açısından Toxoplasma'ya özgül IgG antikorları için taranmalıdır.

Oküler toksoplazmoz, koryoretinit ve körlüğün önemli bir sebebidir. İmmunkompetan kişilerde sıklıkla konjenital enfeksiyonun bir sonucudur ve semptomlar 2.-3. dekata kadar pek ortaya çıkmamaktadır (9). Tüm konjenital toksoplazmozluların 2/3'ünde sonradan koryoretinit geliştiği tahmin edilmektedir. Genellikle bilateraldir ve tedaviden sonra da $\% 30$ oranında nüks görülebilir. İmmunkompromize olanlardaki reaktivasyon ise herhangi bir zamanda kazanılmıs olan enfeksiyona bağlıdır ve genellikle edinsel koryoretinitler tek taraflı olarak ortaya çıkmaktadır.

Konjenital toksoplazmoz, gebelikleri sirasında primer akut toksoplazmoz geçiren kadınların bebeklerinde düşüklere, ölü doğumlara veya doğumsal anomalilere yol açabilmektedir. Konsepsiyondan önceki akut hastalığa bağlı olan konjenital enfeksiyon ihmal edilebilecek kadar az sayıdadır. Enfekte yenidoğanların yaklaşık \%75'i doğumda asemptomatik olmasına rağmen, bu subklinik hastalığ olan çocuklarda sonradan beyin ve gözdeki hasarlara bağlı olarak mental retardasyon veya körlüğe varabilen görme bozukluğu ortaya ç1kabilmektedir. Gebelikte enfeksiyonun hemen tanınması ve tedavi edilmesi bu sekelleri azaltabilmektedir. Ancak bu görüş hakkında kohort meta-analizleri ve bazı prospektif çalışmalar sonucu bazı şüpheler ortaya çıkmıştır (10). Konjenital toksoplazmozun insidansı tam olarak bilinmemekle birlikte olduğundan daha az bildirildiği tahmin edilmektedir. Amerika'da gebelerde insidans \%0.2-1.0 olarak bildirilmiştir (11). Bazı ülkelerde IgM yüksekliği \%2.4'e kadar ulaşabilmektedir (12). Konjenital enfeksiyonun ciddiyeti, annenin gebeliğinin hangi trimestrinde enfekte olduğu ile yakından ilişkilidir. Üçüncü trimestrede alınan bir enfeksiyonun bebeğe bulaşma riski fazla (\%60-65) olmakla birlikte, bu çocukların çoğunda hastalık belirtisi olmamaktadır. Enfeksiyonu gebeliğin ilk trimestrinde alan kadınların bebeklerine geçiş daha 
az (\%15-25) olmakla beraber, düşüğü de içeren ciddi sonuçlar görülmektedir. İkinci trimestrede ise geçiş \%30-45 oranında olmaktadır. Gebelikteki anne enfeksiyonuna bağlı konjenital toksoplazmoz riski yaklaşık olarak \%20 ile \%50 arasında değişmektedir (13). Doğumda toksoplazmoz bulguları 2. trimestrede enfekte olan yeni doğanlarda \%21-28 oranında görülürken, 3. trimestrede enfekte olanların \%11'inden azında saptanmaktadır. Toksoplazmozlu doğanların \%10'unda ciddi hastalık tablosu gözlenmektedir. Konjenital toksoplazmozun en ağır şekli, mental retardasyon, epilepsi ve görme bozuklukları ile seyreden, hidrosefali, serebral kalsifikasyonlar ve koryoretinit tablosudur. Gebelikte akut enfeksiyon tanısı alan annelerin bebeklerine çeşitli yöntemlerle (amniyon sivisında PZR gibi) tanı konmaya çalışılsa da, bazen bu vakalar atlanabilmektedir. Bu durum da riskli olan bebeklerin doğum sonrası takibinin önemini ortaya çıkarmaktadır. Mayıs 2005'te yapılan 8. Uluslararası Toksoplazmoz Kongresi'nde bildirildiğine göre; 1981 ile 2004 yılları arasında, bebekliklerinde primetaminsulfadiyazin kombinasyonu ile tedavi edilmiş 120 kişi takip edilmiş ve tedavi edilememiş veya sadece 1 ay tedavi edilmiş kişilere göre çok daha iyi kognitif, nörolojik ve işitsel sonuçlara ve daha az yeni göz lezyonuna rastlanmıştır (14).

\section{Tanı}

Toksoplasmoz tanısının önemli olduğu 4 klinik grup; gestasyonları sırasında enfeksiyonu geçiren gebeler, konjenital olarak enfekte olan fötus ve yeni doğanlar, immunkompromize hastalar ve koryoretiniti olanlardır. Bu grupların hiçbirinde klinik belirtiler toksoplazmoza özgül değildir ve herbir grupta farklı tanı yöntemlerine ve yorumlamalara ihtiyaç duyulmaktadır (15). Bu hastalarda tanı ile ilgili farklı problemler olmakla birlikte en çok karşılaşılan sorun, gestasyon sirasında bir gebenin akut enfeksiyonunu tanımlamaktır. Eğer bir kadın gebeliğinden önce enfeksiyonu almışsa, immunkompromize olması durumu hariç konjenital toksoplazmoz görülmeyeceği varsayılır.

Akut toksoplazmozun tanısi; kan veya vücut sıvılarından doku kültürü veya hayvan inokülasyonu ile organizmanın izolasyonu, sitolojik preparatlarda veya doku kesitlerinde takizoitlerin ve/veya antijenlerinin gösterilmesi (ör: immunperoksidaz boyama ile), plasenta gibi dokularda veya fötusta ya da yenidoğanda takizoitlerin ve bradizoit içeren kistlerin gösterilmesi, PZR ile Toxoplasma DNA'sının saptanması ve çeşitli serolojik testlerin kullanılması ile konabilmektedir.

\section{Direkt tanı:}

Toxoplasma izolasyonu için fare intraperitoneal olarak hasta materyali ile inoküle edildikten 6-7 gün sonra peritoneal yıkantı sıv1sında takizoitler görülebilmektedir. Eğer görülemediyse, 6-8 hafta sonra beyin gibi organlarda doku kistleri aranır veya serolojik olarak farede enfeksiyon araştırılır. Daha az duyarlı olmakla birlikte, izolasyon işlemi hücre kültür ortamı kullanılarak da yapılabilir. Toplumda $T$. gondii ile karşılaşanların çokluğu ve bunlarda parazitin dokularda latent kalabileceği gerçeği, T. gondii izolasyonunun akut enfeksiyonun tanısındaki değeri üzerinde şüphelere neden olmaktadır. Histolojik tanıda ise, hematoksilen eozin ve PAS yöntemleri ile boyanan preparatlarda çok ince bir duvara sahip kistler içinde bra- dizoit formları PAS pozitif olarak görünür. Eğer doku kistinde çok sayıda bradizoit varsa virgül şeklinde değil de nokta şeklinde görülebilirler. Ayırıcı tanıda daha çok iskelet ve kalp kasında görülen ve daha büyük olan Sarcocystis düşünülmelidir (16). Yaygın enfeksiyonda, periferik kandan hazırlanan boyalı preparatta takizoitler bulunabilmekte veya deri tutulumu olan vakalarda deri biyopsi örneklerinden immunperoksidaz boyama ile tanı konabilmektedir. Ayrica Toxoplasma DNA'sının vücut sıvılarından ve doku örneklerinden temizlenme zamanı tam olarak bilinmediğinden PZR'nun enfeksiyonun zamanı konusunda çok yardimcı olması beklenmemelidir. Bu nedenlerle, serolojik tanı yöntemleri tercih edilmelidir. Ancak organizmaların saptanmasının akut enfeksiyonu işaret edeceği durumlar da bulunmaktadır. Bunlar, beyin omurilik sıvısında, akut pulmoner hastalıkta bronkoalveoler lavaj sivisında ve amniyon sıvisında takizoitlerin saptanması olarak sıralanabilir.

Antijen saptamaya yönelik çalışmalar sırasında, hem $T$. gondii ekstraktlarında hem de yakın zamanda kazanılmış enfeksiyonu olduğu doğrulanmış hastalarda, yüksek reaktiviteye sahip 36 kDa'luk bir antijen saptanmış ve gelecek vaat eden bir yöntem olarak, bu dolaşan antijeni hasta serumunda araştırmak amacı ile bir ELISA yöntemi geliştirilmiştir (16).

\section{Dolaylı tanı}

Serolojik testlerde, hemolizli, lipemik veya kontamine serumlar kullanılmamalıdır. Serumlar, $2-8^{\circ} \mathrm{C}$ 'de 5 günden fazla saklanmamalı, daha uzun süre saklanacaksa $-20^{\circ} \mathrm{C}$ 'ye kaldırılmalıdır. 
Toksoplazmoz tanısında kullanılan antikorlar

\section{Ig G Antikorları}

$\mathrm{Bu}$ antikorların kantitasyonu, SabinFeldman testi ve toksoplazmoz için uluslararası standart serum preparasyonun geliştirilmesinden sonra mümkün olmuştur $(17,18)$. Bu adımlar, dünyada değişik laboratuvarlarda toksoplazmoz serolojisinin standardizasyonunda da önemlidir. Ig $G$ antikorları genellikle enfeksiyonun 2 . haftası civarında ortaya çıkmakta, 6-8 haftada en yüksek düzeyine ulaşmakta ve değişen oranlarda düşerek genellikle hayat boyu pozitif kalmaktadır. Titre, hastalığın şiddeti ile orantılı değildir. Sabin-Feldman testi, ELISA, IHHA, IFA gibi testler kullanılarak özgül IgG antikorları saptanabilir.

\section{Ig M Antikorları}

T. gondii enfeksiyonunda ilk oluşan antikorlar olup çoğu vakada bir kaç ay sonra negatifleşmektedirler. İmmunkompetan kişilerde duyarlı bir test ile negatif çıkması akut enfeksiyonu ekarte ettirecek bir bulgudur. Ancak pozitif çıkmas1 çoğu zaman akut enfeksiyona karar vermek için yeterli bir kriter olmayabilir. Bazı akut enfeksiyonlarda pozitiflik aylar hatta yıllar boyunca devam edebilmektedir ancak bunun klinik bir önemi yoktur ve enfeksiyon kronik olarak kabul edilmelidir (19). "Çift-sandviç" veya "immun-capture"(yakalama) IgM ELISA yöntemi, romatoid faktör veya antinükleer antikorların varlığında yanlış pozitif sonucu büyük ölçüde engellemektedir.

\section{Ig A Antikorlari}

Toxoplasma enfeksiyonunda erken dönemde meydana gelmekte ve 3-9 ay arasında düşmektedir. ELISA veya ISAGA (immunosorbent agg- lutination assay) metodları kullanılarak akut erişkin enfeksiyonunda, aktif hastalı̆̆ı olan veya olmayan immunkompromize hastalarda ve konjenital olarak enfekte olmuş yenidoğanlarda saptanabilir (20). Erişkinde Ig M'de olduğu gibi aylarca devam edebilir. Oysa konjenital toksoplazmozda Ig A antikor testlerinin duyarlılığı, Ig M testlerinden daha fazladır. Bazı konjenital toksoplazmoz vakalarında, Ig $M$ antikorları saptanamamasına rağmen Ig A ve Ig $G$ antikorları saptanarak tanı konabilmektedir. Öte yandan IgM ve IgA antikorları, konsepsiyondan hemen sonra al1nan enfeksiyonlarda, 2. trimestrede bile pozitifleşebilir.

\section{Ig E Antikorlari}

Akut enfeksiyonda, konjenital olarak enfekte bebeklerde ve konjenital toksoplazmik koryoretiniti olan çocuklarda ELISA ile saptanır (21). Ig M ve Ig A'dan daha kısa sürelidir. İmmunkompromize hastalarda IgE bulunması koryoretinit veya hastalık reaktivasyonu gibi komplikasyonlarla ilişkilendirilmiştir.

\section{Serolojik yöntemler}

\section{Sabin-Feldman Testi}

Sabin ve Feldman tarafından 1948'te serolojik bir boya testi tanımlanmıştır (22). Sabin-Feldman testi (SF) veya Toxoplasma lizis testi halen "altın standart" olarak kabul edilmektedir. Son derece duyarlı ve özgül bir yöntemdir. Takizoitlerin Toxoplasma antikorları ve kompleman varlığında lizisine dayanmaktadır. Tüpte veya mikroplakta yapılabilir. Dilüe edilmiş hasta serumları ve takizoitler, aktivatör serum varlığında $37^{\circ} \mathrm{C}$ 'de inkübe edilir. Takizoitlerin \%50'sinin canlılı̆̆ını yitirdiği dilüsyon, son dilüsyon olarak kabul edilir. Taki- zoitlerin canlılıkları, faz kontrast mikroskopta incelenerek veya metilen mavisi ile boyanarak anlaşlabilir. Faz kontrast mikroskopta kararmış olarak görünen ölü takizoitler, alkali metilen mavisi ile de boyanmazlar. Sonuçlar, titre veya referans serum ile karşılaştırılarak "iu" cinsinden verilebilir. Pozitif test, hastanın parazit ile karşılaştığını gösterir. Bu testin saptadı̆̆ antikorlar (IgG) enfeksiyonun edinilmesinden 1-2 hafta sonra ortaya çıkar, 6-8 hafta sonra en yüksek değerine ulaşıp, 1-2 yılda yavaşça azalırlar ve düşük titrelerde ömür boyu saptanırlar. Negatif SF testi, eğer hasta hipoglobulinemik değil ise, $T$. gondii ile karşılaşılmadığını gösterir. Sabin-Feldman boya testi, BOS'nda serumdan daha yüksek titrede bulunduğunda akut toksoplazmoz açısından değerli olabilir. Öte yandan, toksoplazmik koryoretiniti ve ensefaliti olan immunkompromize vakalarda da, $T$. gondii spesifik IgG antikorları bulunmayabilir.

\section{Ayırtedici Aglutinasyon (AC/HS) testi}

Bir tanesi akut enfeksiyonu takiben erken dönemdeki (AC), diğeri de enfeksiyonun geç evrelerindeki (HS) antijenik determinantları içeren iki antijen preparasyonu kullanılmaktadır. AC testi, aseton veya metanol ile tespit edilmiş takizoitler ile uygulanırken, HS testinde formalin ile tespit edilmiş takizoitler kullanılmaktadır. Serumlar, merkaptoetanol içeren tampon içinde sulandırılır ve direkt aglütinasyon testi uygulanır. Eğer pozitif çıkarsa, ayırtedici aglütinasyon testine başlanır. AC aglütinasyon titresinin HS'ye oranı akut, eşik değerde ve akut olmayan reaktivite paternini gösterir. Akut patern, enfeksiyonu takiben 1 yil veya daha fazla devam edebilir. Diğer testler ile birlikte kullanıldığında akut enfeksiyonu kronikten ayır- 
mada faydalı olabilen bir yöntem$\operatorname{dir}(23)$.

\section{İndirekt immunfloresan antikor testi (IFAT)}

Yapılması kolay, güvenli ve ekonomiktir. SF testi ile aynı tip antikorları ölçmekte ve titreleri paralellik göstermektedir. Bazı ANA(+) serumlarla yalancı pozitif sonuç verebilir. Düşük serum IgG seviyelerinde yalancı negatif sonuç alınabilir. IgG veya IgM'e karşı hazırlanan antiserumla çalışılabilir.

\section{İndirekt Hemagglutinasyon Testi (IHA)}

Sabin-Feldman testi ve IFA testine göre daha geç pozitifleştiği için gebelerde akut infeksiyon tanısında, yalancı negatif sonuçları nedeniyle de konjenital toksoplazmoz tanisinda kullanılmaz.

\section{Anti-Toxoplasma IgM ELISA (immun-yakalama veya çift- sandviç)}

Örnekteki IgM sınıfı antikorlar, öncelikle plağa kaplanmış olan antiinsan IgM antikorları ile yakalanır. Serumdaki, özellikle IgG'yi de içeren, tüm diğer bileşenler yıkandıktan sonra özgül IgM antikorlarının tüm IgM antikorları içinde saptanması için enzimle konjuge özgül monoklonal antikor ile işaretli antijen ortama eklenir. İnkubasyondan sonra bağlanmayan konjugatı uzaklaştırmak amacı ile kuyucuklar yıkanır ve kromojen/substrat ortama eklenir. Enzim varlığında, renksiz olan substrat renkli bir son ürüne dönüşür ve örnekteki özgül IgM antikorları ile orantılı olan optik dansitesi ölçülerek sonuç belirlenir (24).

\section{IgM Immunosorbent Aglutinasyon Testi (IgM ISAGA)}

Hastaya ait IgM tipi antikorların katı bir yüzeye yapıştırılıp formalinle tespit edilmiş organizma veya antijenle kaplı lateks parçacıklarıyla karşılaştırılması prensibine dayanır. Aynı teknikle IgA ve IgE tipi antikorlar da saptanabilir. Diğer IgM saptayan testlere göre daha duyarlı sonuçlar vermektedir. $O$ nedenle gebelerde kullanılması tavsiye edilmemektedir (25).

\section{Anti-Toxoplasma IgG ELISA}

Sulandırılmış serum örnekleri, antijenle kaplanmıs olan kuyucuklarda özgül antikorların bağlanması için inkübe edilir. Bağlanmayan antikorlar ve diğer serum elemanları yıkandıktan sonra $T$. gondii özgül antikorları, enzimle konjuge edilmiş anti-insan IgG antikorları kullanılarak saptanır. İnkubasyondan sonra, bağlanmayan konjugat yıkanarak uzaklaştırılır ve substrat ortama eklenir. Antikor varlığına göre bir renk reaksiyonu ortaya çikar. Reaksiyon durdurularak, optik dansiteler okutulur. Kitlerin içlerinde bulunan International Standard for Anti-Toxoplasma seruma (code TOXM) göre ayarlanmiş standartlar kantitasyon amacıyla kullanılmaktadır.

\section{Anti-Toxoplasma IgG Avidite}

Hedman ve arkadaşlarının 1989'daki çalışmalarından beri akut toksoplazmoz tanısındaki rolü araştırılmaktadir (26). Toxoplasma'ya özgü Ig G antikorlarının aviditesinin (fonksiyonel afinite) ölçülmesine dayanır. Antijen ile karşlaşmadan sonra oluşan antikorların ortalama aviditesi genellikle düşüktür. Bağışık yanıtın gelişimi sırasında haftalar veya aylar içinde antikor aviditesi olgunlaşır. Ig G'nin fonksiyonel afinitesindeki artış, antijen kaynaklı bir B hücre seçimi sonucu, antijen-antikor bağlanma yerindeki uygunluğun artmasına bağlıdır. Antikorun antijene bağlanması, hidrojen bağı gibi kimyasal güçler veya elektrostatik Van der Waals ilişkisi yolu ile sağlanmaktadır. ELISA sırasında, immobilize antijene bağlanan düşük aviditeli (fonksiyonel afinite) IgG, üre gibi ajanların varlığında antijenden kolaylıkla ayrilırken, yüksek aviditeli olanlar ayrılmayacaktır. Bu nedenle avidite, iki set halinde Toxoplasma IgG ELISA yapilarak belirlenir. Bunlar arasındaki fark, ilk inkubasyondan sonra bir setin üre içeren tampon ile diğerinin ise üre içermeyen tampon ile yıkanmasıdır. Üre ile muamele edilmiş ve edilmemiş örneklerin optik dansiteleri oranlanarak avidite indeksi (AI) bulunur. Bu göreceli avidite indeksi, üreye dirençli ve toplam Ig G'nin oranını temsil eder. Örnek olarak, $A \dot{I}<0,20$ düşük avidite, 0,20-0,25 eşik değer ve $A \dot{I}>0,25$ yüksek avidite şeklinde yorumlanabilir $(27,28)$.

Çeşitli klinik durumlarda tercih edilen değişik materyal ve testler bulunmaktadır. Annede şüphe edilen bir enfeksiyon varsa, serum ve amniyon sıvısı (>1ml) örneklerinde S-F testi, IgG ve IgM ELISA ve gerekli olan diğer testler yapılmalıdır. Konjenital toksoplazmoz şüphesi olan yenidoğan ve bebeklerde ise kordon kanı (serum) ve serumda S-F testi, IgM ve A ISAGA ile IgG ve IgM antikorları aranmalıdır. Organ transplantasyonu öncesinde serumda IgM, IgG ELISA ve S-F testi ile antikorlar aranmali ve $B O S$ 'ta $P Z R$ düşünülmelidir. Oküler toksoplazmozda, serum, aköz humor ve vitreus sivisında S-F testi, IgM ve IgG ELISA ile antikor bakılırken, lokal olarak PZR de uygulanabilir

\section{Serolojik testlerin yorumlanmasi}

Değişik serolojik testler, enfeksiyondan sonra kendilerine özgü yükseliş ve düşüş paternleri gösteren değişik antikorları ölçmektedir. Hastalarda bağışıklık durumunu 
anlamak amacı ile ilk olarak IgG antikorlarına bakılmalıdır. IgG antikorları pozitif olan bir kişi, geçmişte herhangi bir zamanda enfekte olmuş demektir. Üç hafta arayla yapılan tetkiklerde IgG antikorlarında titre artışı saptanmıyorsa infeksiyonun iki aydan daha eski olduğu; titre artışı var veya IgM pozitifliği de saptanıyorsa infeksiyonun daha yeni olduğuna karar verilebilir. Eğer titre artışı saptanıyor ve IgM negatif sonuç veriyorsa bu durumda reaktivasyondan şüphelenilmelidir. Akut edinsel toksoplazmozu bulunan bir kişi hem IgG hem de IgM antikorları için pozitif olabilirken, reaktivasyonu olan birinde normalde IgM cevabı oluşmaz ve IgG antikorlarında bir artış olması da kesin değildir. O nedenle tanı koymak da zorlaşmaktadır. Toksoplazmoz tanısında genellikle geç dönemde serolojik testlere başvurulduğu için çoğunlukla antikorlar yüksek seviyeye ulaşmış olur ve uzun süre yüksek kalabileceği için akut enfeksiyonu belirlemede aralıklı alınan iki serumda çalışılmasının çok fazla faydası olmamaktadır. Bir kişinin yeni mi yoksa eskiden mi enfekte olduğunu belirleyebilmek için sıklıkla kombine serolojik testlere ihtiyaç duyulmaktadır. Pozitif IgM sonucunun yanlış yorumlanma potansiyeli yüksek olduğu için doğrulayıcı testler yapılmalıdır. IgM testlerinde romatoid faktör, blokan antikor ve anne immunglobulinlerine karşı oluşmuş fötal IgM antikorları nedeniyle hem yalancı pozitif hem de yalancı negatif sonuçlar alınmaktadır. IgM yakalama testi bu özgül olmayan reaksiyonları engelleyebilmektedir. Bazı hastalarda IgM antikorları 1 yıldan uzun süre pozitif olarak kalabilir (16). Amerika'da FDA onaylı kitlerle IgM pozitif bulunan serumların referans laboratuvarda daha ileri değerlendirilmesi sonucu, hastaların \%60'inda akut olmayan enfeksiyon olduğu görülmüştür
(29). Amerika'da FDA onayı almıs olan kitlerle ilgili olarak yanlış pozitif sonuçların fazla olduğuna dair gelen raporlar sonucu FDA, bu testlerin duyarlılık ve özgüllüklerinin tekrar gözden geçirilmesi için Amerika'daki referans laboratuvarlarının yürüttüğü bir çalışmayı desteklemiştir. Bu çalışmanın sonuçlarına göre, A.B.D.'de değisik ticari kitlerin Toxoplasma'ya özgül IgG ve IgM antikorlarını saptamadaki özgüllükleri \%77 ile \%99 arasında değişmektedir (30). Bu nedenle FDA, IgM pozitifliğinin bir referans laboratuvarda doğrulanmasını istemektedir. Toksoplazmozla ilgili yanlış uygulamaları engellemek için laboratuvar çalışanı ticari kitlerle ilgili problemleri anlamalı ve sonuç bekleyen klinisyene hastanın antikor durumunu belirlemede testin yararı konusunda mümkün olan tüm bilgileri vermelidir. Klinisyen de, IgM sonucu pozitif olan bir hastaya danışmanlık vermeden önce testlerle ilgili sorunlar ve tedavi seçenekleri konusunda kendisini eğitmelidir. Bunun yanında, Ig M antikorları özellikle IgM ISAGA gibi çok duyarlı testler kullanıldığında uzun süre saptanmaktadır. O yüzden bu test metodunun gebelerde kullanılması önerilmemektedir. İmmunkompromize hastalarda ve oküler lezyonu olanlarda da IgM testleri tanıya fayda sağlamayabilmektedir. Günümüzde, daha özgül, duyarlı ve akut enfeksiyonu ayırtedebilen testler geliştirilmeye çalışılmaktadir. 2004 yılında otomatize bir sistemle (floromanyetik bilyaları antijen ile kaplayarak) akut vakalarda özgül IgM antikorlarını ölçen bir yöntem tanımlanmıştır (11). İmmunkompetan bir erişkinde özgül IgG ve IgM sonuçlarının yorumu Tablo-1'de özetlenmiştir.

Amerika'da ve Avrupa'da referans laboratuvarlarda akut toksoplasmozun tanısı için birçok serolojik testin kombinasyonu kullanıl- maktadır. Sabin-Feldman testi, IgG ELISA, IgM ELISA (yakalama), ayırdedici aglütinasyon testi $(\mathrm{AD} /$ HS testi), IgG avidite testi, IgA/E ELISA, IgM/IgA ISAGA bunlardan bazılarıdır. Klinik duruma göre bu testlerden gerekenlerini kullanarak akut toksoplazmoz tanısı koymak, toksoplazmik lenfadenit, miyokardit, polimiyozit, koryoretinit ve gebelik sırasında klinik fayda sağlamaktadır. Böylelikle, özgül IgG ve Ig M pozitifliğinin akut bir enfeksiyona mı bağlı olduğu tek bir testten daha iyi ortaya konmaktadır. Ig $G$ avidite testinin de tek başına yeni veya eski enfeksiyonu ayırtedebilme gücü sınırlıdır; çünkü gebelik sırasında serokonversiyon gösteren gebelerin Ig G avidite kinetikleri çalışıldığında, yüksek aviditeye sahip kadınların $T$. gondii ile en az 3-5 ay önce enfekte olduğu (kullanılan metoda göre değişmek üzere) ancak düşük aviditeli antikorlar aylar boyunca pozitif kalabildiğinden varlıklarının her zaman yeni kazanılmıs bir enfeksiyonu göstermeyebileceği bulunmuştur (31).

\section{Oküler toksoplazmoz}

Oküler toksoplazmoz, genellikle konjenital enfeksiyon sonucudur ve sıklıkla $T$. gondii'ye özgül serum IgG antikorlarının düzeyinde bir artış meydana gelmediği gibi IgM antikorlarına da rastlanmaz. $\mathrm{Bu}$ nedenle seroloji daha çok seronegatif kişilerde oküler toksoplazmozun ekarte edilmesi açısından faydalıdır. Aköz humorda $T$. gondii'ye özgül immunglobulinler saptanarak, PZR veya kültür ile parazit izolasyonu yapılarak tanıya gidilebilir. Aköz humordaki özgül antikorların, serumdaki özgül antikorlara oranlanmasına Goldmann-Wittmer katsayısı denmektedir ve 3 'ten fazlaysa aktif enfeksiyon açısından önemli olarak kabul edilmektedir. Ancak oküler sıvılar kolay elde edilemediğinden 
bu tür araştırmalar da pek mümkün olamamaktadır. Eğer göz bulguları akkiz toksoplazmoza bağlı ise, hastanın hikayesinde influenzaya benzer bir hastalık veya lenfadenopati gibi bulgular bulunabilir ve serumda da IgM pozitifliği saptanabilir. Tanıda, göz sıvılarında veya periferik kan serumunda western blot da uygulanabilir. ise, gebe duyarlıdır ve korunma önlemlerini vurgulanmalı ve düzenli vizitlerde seroloji önerilmelidir. Özgül Ig G pozitif ise IgM istenmelidir. Pozitif ise olası enfeksiyon olarak kabul edilip tedaviye başlanmalı ve gebeliğin zamanı, çift serum örnekleri, başka serolojik testler ve PZR ile annede akut enfeksiyon tanınmaya çalışılmalı- sif olarak geçen IgG antikorları bulunur. Bu antikorların titreleri yüksek olabilir ama bu durum enfeksiyonu göstermez. Plasenta bariyerini geçemeyen IgM antikorlarının yanidoğanda saptanması, enfeksiyonun daha gerçekçi bir göstergesidir. Bununla birlikte, tek bir serum örneğinde Ig M pozitifliği, romatoid faktör ve antinükleer

Tablo 1. Ticari kitlerle elde edilen Toxoplasma seroloji sonuçlarının yorumlanması

\begin{tabular}{|c|c|c|}
\hline $\begin{array}{l}\text { IgG } \\
\text { sonucu }\end{array}$ & IgM sonucu & Erişkinlerde sonuçların yorumu \\
\hline Negatif & Negatif & T. gondii enfeksiyonunu gösteren serolojik bulgu yok \\
\hline Negatif & Eşik değer & $\begin{array}{l}\text { Olası erken akut enfeksiyon veya yalancı IgM pozitifliği; yeni örnekle çalış (2 hf sonra); eğer sonuç aynı } \\
\text { olursa, hasta büyük olasılıkla T. gondii ile enfekte değildir. }\end{array}$ \\
\hline Negatif & Pozitif & $\begin{array}{l}\text { Olası erken akut enfeksiyon ya da yalancı IgM pozitifliği yeni örnekle çalış; eğer sonuç aynı olursa, IgM } \\
\text { reaksiyonu büyük olasılıkla yanlış pozitifliktir. }\end{array}$ \\
\hline $\begin{array}{l}\text { Eşik } \\
\text { değer }\end{array}$ & Negatif & Belirsiz; yeni örnekle veya aynı örneği farklı bir lgG testi kullanarak çalış. \\
\hline $\begin{array}{l}\text { Eşik } \\
\text { değer }\end{array}$ & Eşik değer & Belirsiz; yeni örnekle tekrar çalış. \\
\hline $\begin{array}{l}\text { Eşik } \\
\text { değer }\end{array}$ & Pozitif & $\begin{array}{l}\text { Olası akut enfeksiyon; yeni örnekle tekrar çalış; Eğer sonuçlar aynı kalır veya IgG sonucu pozitifleşirse } \\
\text { akut enfeksiyon şüphesi, doğrula }\end{array}$ \\
\hline Pozitif & Negatif & 6 ay-1 yıldan uzun zamandır T. gondii ile enfekte \\
\hline Pozitif & Eşik değer & $\begin{array}{l}\text { Büyük olasılıkla } 1 \text { yıldan uzun süredir enfekte ve yalancı veya uzamış IgM pozitifliği; IgM testini yeni } \\
\text { örnekle tekrarla; Eğer sonuç aynı olursa, daha ileri tetkikler }\end{array}$ \\
\hline Pozitif & Pozitif & Son 12 ay içinde geçirilen olası yakın enfeksiyon; doğrula \\
\hline
\end{tabular}

\section{Gebe, fetus ve yenidoğan}

Türkiye'de gebelik öncesinde ve sırasinda serokonversiyonu saptamak amacı ile yürütülen bir tarama programı bulunmamaktadır. Dolayısıyla ülkemizde, gebelikte edinilmiş bir enfeksiyon olup olmadığı çoğunlukla gebelik sırasında alınan tek bir serum örneğinden anlaşılmaya çalışılmaktadır. Fransa'da gebelerde yakın zamanda kazanılmış enfeksiyonu tanımlamak için seronegatif kadınlarda aylık kontroller yapılmaktadır. Literatürdeki pek çok bilgi de bu tecrübelere dayanmaktadır. Laboratuvarın amacı zamanında ve uygun bir klinik müdahale yapılabilmesi için gebenin klinik durumu hakkında veriler sağlamaktır. Gebenin geçmiş Toxoplasma serolojisi bilinmiyorsa, Ig $G$ antikorlarına bakılır. Negatif dır. Eğer annede akut enfeksiyon tanısı konursa, fötus amniyon sıv1sinda PZR ve USG ile incelenmeli, fötus enfekte ise aileye danışmanlık verilmeli ve değilse de gebeliğin sonuna kadar tedaviye devam edilmelidir.

Sağlıklı insanlarda Toxoplasma Ig G prevalansı yüksektir ve genelde hayat boyu devam eder. Genellikle Ig M, Ig A veya Ig E Toxoplasma antikoru test sonuçları da tek serum örneğinde, yakın zamanda veya daha önceden geçirilmiş enfeksiyonu ayırmada güvenilir sonuç vermemektedir. Akut ve konjenital enfeksiyonda IgM ve IgA antikorları ilk saptanacak antikorlardır. Yeni doğanlarda testlerin yorumlanmasında bazı zorluklar bulunmaktadır. Özgül antikorları olan annelerin bebeklerinde pa- antikor varlığında yanlış pozitiflik veya antijen reseptörlerinin IgG ile satürasyonu sonucu yanlış negatiflik nedenleriyle yeni enfeksiyonu göstermeyebilmektedir. Doğumdan sonra da ilk birkaç hafta yükselip sonra 1 yıl veya daha fazla kalabilirler. Ayrica, Ig M ve/veya Ig A antikorları da doğum sırasında anneden bebeğe geçebileceği için yenidoğandaki Ig M ve Ig A antikorlarının yorumunun da dikkatli yapılması gerekmektedir. Ig M ve Ig A antikorlarının yarılanma ömürleri kısa olduğundan, Ig M pozitifliğinde hayatın 2.-4. gününde ve Ig A pozitifliğinde ise hayatın 10. gününde test tekrarlanmalıdır. Bunun yanında bazı konjenital toksoplazmozlu yenidoğanlar Ig M ve/veya Ig A antikorları açısından negatif de olabilmektedirler. Böyle bebeklerde Ig $\mathrm{G}$ antikorlarının be- 
beğe mi anneye mi ait olduğunun saptanması için 6 ay süre ile aylık Ig $G$ antikor testinin yapılması gerekebilmektedir. Anneden geçen antikorlar her ay yarılanacaktır. Fötus ve yenidoğanda enfeksiyon tanısı ile ilgili çalışmalar yapılırken, anne-bebek çiftinde western blot çalışılmasının faydası ortaya çıkmıştır. Remington ve meslektaşları 1985'te, anne ve bebek serumlarının Ig $M$ ve Ig $G$ western blotlarında değişik bantların görüldügünü ortaya koydular (32). Western blotlar ve Ig M ISAGA'nın beraber kullanılması ile konjenital toksoplazmozun erken tanısındaki duyarlılığın \%91.3'e yükseldiği gösterilmiştir. Doğumdan sonraki ilk haftalarda pozitif sonuç görülemeyebileceğinden, erken western blot sonuçları dikkatli yorumlanmalıdır. Bunun yanında gebelikte prenatal tedavi veya postnatal olarak bebeğin tedavisi de yanlış negatif sonuçlara yol açabilmektedir. Bebeğin blotunda, anne blotunda görülen bantların daha yoğun olarak görülmesi, sağlıklı bebeklerde de görülebilen bir tablo olabildiğinden bir pozitiflik kriteri olarak kabul edilmemelidir. Sistematik gebe taramasının yapılmadığı ülkelerde konjenital toksoplazmozun tanısında, hayatın ilk aylarında Ig M ve Ig A ELISA ve ISAGA gibi diger testlerle beraber western blot da kullanılabilir. Yine de tüm bu testlerle tek tek veya birlikte tüm konjenital toksoplazmoz vakalarina tanı konamayabilmektedir. Böyle erken tanı konamayan vakalarda risk altında olan tüm yeni doğanlarin tekrarlayan testlerle takip edilmesi önem kazanmaktadır. Bazı vakalarda, sentezi 4-5 ay geciken özgül Ig G antikorları konjenital enfeksiyonun tek işareti olabilmektedir. Konjenital enfeksiyonlu bebeklerin \%94'üne hayatlarının ilk 3 ayında western blot ve diğer serolojik testler beraber uygulanarak tanı konabilmektedir. Avrupa'da araştırmacılar, anne-yenidoğan blotunu Ig G, A ve M için konvansiyonel serolojiden daha üstün bulmazken; Amerika'daki araştırmacı-

Tablo 2. Toksoplazmoz tanısında Sabin-Feldman test sonuçlarının yorumlanması*

\begin{tabular}{|c|c|c|c|c|c|}
\hline \multirow[t]{2}{*}{ Klinik durum } & \multicolumn{5}{|c|}{ Aşağıdaki titrelerde enfeksiyon yorumu } \\
\hline & negatif & $1: 16$ & $1: 64$ & $1: 256$ & $\geq 1: 1024$ \\
\hline Asemptomatik & $\begin{array}{c}\text { Enfeksiyona } \\
\text { duyarlı }\end{array}$ & $\begin{array}{c}\text { Geçmişte } \\
\text { enfeksiyon, } \\
\text { bağışık }\end{array}$ & $\begin{array}{c}\text { Geçmişte } \\
\text { enfeksiyon, } \\
\text { bağışık }\end{array}$ & $\begin{array}{c}\text { Geçmişte } \\
\text { enfeksiyon, } \\
\text { bağışık }\end{array}$ & $\begin{array}{c}\text { Yeni enfeksiyon } \\
\text { veya reenfeksiyon }\end{array}$ \\
\hline Gebelik & $\begin{array}{c}\text { Enfeksiyona } \\
\text { duyarlı }\end{array}$ & $\begin{array}{l}\text { Geçmişte } \\
\text { enfeksiyon, } \\
\text { bağışık }\end{array}$ & $\begin{array}{c}\text { Geçmişte } \\
\text { enfeksiyon, } \\
\text { bağışık }\end{array}$ & $\begin{array}{c}\text { Geçmişte } \\
\text { enfeksiyon, } \\
\text { bağışık }\end{array}$ & $\begin{array}{c}\text { Yenidoğanın } \\
\text { enfeksiyon için } \\
\text { monitorizasyonu }\end{array}$ \\
\hline $\begin{array}{c}\text { asempt. veya sarılıklı } \\
\text { yenidoğan, }\end{array}$ & Yok & Yok & Tanı olası değil & Tanı olası değil & $\begin{array}{l}\text { Enfeksiyon olası, } \\
\text { IgM testi uygula }\end{array}$ \\
\hline Ensafalitli yenidoğan & Yok & Yok & Yok & Tanı olası değil & $\begin{array}{c}\text { Titre sabit kalır } \\
\text { veya yükselirse } \\
\text { tanı doğru olabilir, } \\
\text { IgM testi uygula }\end{array}$ \\
\hline lenfadenopati & Yok & Yok & Yok & Tanı olası değil & Tanı olası \\
\hline $\begin{array}{l}\text { Pnömoni, myokardit } \\
\text { veya hepatit ve ateş }\end{array}$ & Yok & Yok & Tanı olası değil & Tanı olası değil & $\begin{array}{c}\text { Tanı olası, IgM } \\
\text { testi uygula }\end{array}$ \\
\hline koryoretinit & Yok & Tanı olası & Tanı olası & Tanı olası & Tanı olası \\
\hline ensefalit & Yok & Yok & Tanı olası değil & Tanı olası değil & $\begin{array}{c}\text { Tanı olası, IgM } \\
\text { testi uygula }\end{array}$ \\
\hline $\begin{array}{c}\text { Ensefalit } \\
\text { (immunkompromize) }\end{array}$ & Tanısal değil & $\begin{array}{c}\text { Tanı olası değil } \\
\text { (transfüzyon } \\
\text { kaynaklı olabilir) }\end{array}$ & Tanı olası & Tanı olası & $\begin{array}{c}\text { Tanı lehinde, IgM } \\
\text { testi uygula }\end{array}$ \\
\hline
\end{tabular}

\footnotetext{
* 16. kaynaktan uyarlanmıştır.
} 
lar, Ig A ve Ig M toksoplazma antikorları gösterilemeyen hastalarda bu yöntemi faydalı bulmaktadır.

Gebelikte kazanılmış enfeksiyonu, fötal enfeksiyonu ve risk altındaki yeni doğanda enfeksiyonu tanımak amaciyla bazı metodlar öne çıkmıştır. Serum Ig $G$ avidite testi, vucut siviları ve dokularda polimeraz zincir reaksiyonu (PZR) ve anne-bebek serum çiftinde çalış1lan western blot gibi testler yeni kazanılmış enfeksiyonu göstermede aydınlatıcı olmaktadır.

Avidite testi yardımı ile yeni veya kronik enfeksiyonun ayırt edilmesi, gebelikte yanlış tanı olasılığını, tanıyı doğrulamak veya takip için ihtiyaç duyulan testlerin sayısını ve spiramisine ihtiyacı azaltacak; daha invaziv testlere gerekliliği de ortadan kaldıracaktır. Günümüzde kullanılan metoda bağlı olarak, avidite testleri ile son 4-5 aydan önce geçirilen enfeksiyon saptanabilmektedir. Bu test, özellikle gebeliğinin ilk aylarında Ig G ve Ig M Toxoplasma antikorları pozitif olan kadınlarda, doğrulayıcı bir test olarak kullanılmaktadır. Örnek olarak, gebeliğinin ilk trimestrinde yüksek aviditesi olan bir kadın enfeksiyonu 3 aydan önce almış olarak yorumlanabilir. Konjenital geçişin, konsepsiyondan önceki ve civarındaki haftalarda alınan enfeksiyondan kaynaklanma olası̆ğ dikkate alınmayacak kadar düşüktür. Avidite testi, özellikle ülkemizdeki gibi gestasyonun başında alınan tek serum örneği ile karar verilen ülkelerde önem kazanmaktadır. Tek serumda yakın enfeksiyon ekarte edilemediğinden spiramisin tedavisi önerilen 40 kadından \%17.5'inde yüksek aviditeli antikorlar tespit edilmiştir. Bu hastalar arasında S-F testi 1:1024 ve Ig $M$ antikoru pozitif olan hasta da bulunmaktadır (33). Çeşitli hasta gruplarında S-F test sonuçlarının titrelerine göre yoru- mu Tablo-2'de özetlenmiştir. Ig M antikorlarının varlığında, Ig G avidite testinin düşük çıkması, her zaman hastanın son zamanlarda bir enfeksiyon aldığ mektedir. Düşük avidite değerleri de bir y1l kadar devam edebilmektedir. Bunun yanında, bazı hastalarda sonuçlar gri alanda çıkabilmektedir. Ig $G$ antikoru pozitif bulunan ama Ig M antikoru saptanamayan kadınların \%40'ında sınırda veya düşük avidite saptanmıştır (31). Düsüuk veya sınırda avidite testi sonucu olan hastalarda diğer serolojik testlere bakılarak karar verilebilir. Bu sebeple Amerika ve Avrupa'da referans seroloji laboratuvarlarında değişik hasta grupları için değişik tanı panelleri (ELISA Ig M (yakalama), Ig E, Ig A, IgG, S-F testi, ayırt edici (diferansiyel) aglütinasyon, direkt aglütinasyon, IgM ve IgA ISAGA, immunoblot) kullanılmaktadır. Yenidoğanlarda ve immun sistemi baskılanmış olanlarda avidite testinin tanısal değeri düşüktür. Tek başına belirleyici bir testten çok diğer serolojik testlerle beraber doğrulama testi olarak kullanılmalıdır (34).

\section{PZR}

PZR, özellikle konjenital, okuler toksoplazmozda ve immunkompromize hastaların serebral ve yaygin enfeksiyonlarının tanısında başarıyla kullanılmaktadır (35). Materyal olarak amniyon sivisi, serebro-spinal sıvı, idrar, vitreus s1vıs1, aköz humör, bronko-alveoler lavaj sıvısı, plevra ve periton sıvıları, kan, plasenta ve beyin dokuları kullanılmaktadır. PZR en sık konjenital enfeksiyonun prenatal tanısında kullanılmaktadır. Çoğu laboratuvarda, 35 tekrarlı B1 geni kullanılmaktadır. T. gondii genomunda 300 defa tekrarlanan bir DNA fragmanı olan AF146527 sekansı da kullanılmaya başlanmıştır. Fransa'da, gebelik sırasında enfekte olan annelerden doğan 44 bebekte üç PZR hedefi (18S ribozomal DNA, B1 ve AF146527) ve fare inokülasyonu karşılaştırılmıştır. Bu üç hedefe yönelik PZRnun duyarlılığı ve özgüllüğ̈̈ arasında istatistiksel olarak anlamlı bir fark bulunamamıs ama daha ileri araştırmalara ihtiyaç duyulduğu bildirilmiştir (36). PZR testi için gönderilen materyal DNA degradasyonu engellemek için vakit geçirilmeden laboratuvara ulaştırılmalıdır. Gönderilecek sıvılar santrifüj yapılmamalıdır çünkü bu işlem yanliş negatif sonuçlara yol açabilir. Eş zamanlı olarak serum örnekleri de serolojik testler için gönderilmelidir. Kontaminasyona bağlı olarak yanlış pozitif sonuçlar alınabilir. PZR, ölü ve canlı organizmayı, takizoit ve bradizoiti ayırt edemez. Bu nedenlerle, serolojik testlerle beraber yorumlanmalıdir.

3 evreli konvansiyonel PZR (ekstraksiyon, amplifikasyon ve deteksiyon) için değişik laboratuvarlarda değişik protokoller uygulanmaktadir. Bu farklar, DNA ekstraksionu, primer seçimi, taşıma kontaminasyonu engellemek için uracyl-DNA-glycosylate enziminin kullanılması, başlangıç 1sıtması yapılması, PZR ürününün büyüklüğü ve internal kontrolün veya nested PZR'nun kullanılması gibi faktörlerden kaynaklanmaktadır. Prenatal tanı büyük ölçüde USG ve amniyon sıvısında yapılan PZR'na dayanmaktadır. 18. haftadan itibaren amniyon sivisinda $T$. gondii DNA'sını aramanın fetal blood sampling işlemini içeren konvansiyonel tanısal yöntemlerden daha çabuk, duyarlı ve güvenli bir yöntem olduğu gösterilmiştir (37). Gebelikte enfeksiyonu aldığı serolojik testler ile kanıtlanmış veya kuvvetle muhtemel tüm gebelerde amniyon sıvisında PZR yapılmalidır. Ayrica USG ile fetal hasarın saptandı̆̆ı durumlarda da (hidrosefali ve/veya kalsifikasyonlar) uygulanmalıdır. 18 haftadan önce 
yapılan PZR testinin güvenilirliği konusunda bir bilgi yoktur. Amniyotik sıvı PZR'nun konjenital toksoplazmoz için özgüllük ve pozitif prediktif değerinin \%100'e yakın olduğu bildirilmiştir. Duyarlılık ve negatif prediktif değeri ise enfeksiyonun alındığı gebelik haftasına göre değişmektedir. PZR ile prenatal tanı duyarlılığı, 17-21. haftalarda alınan enfeksiyonda önemli derecede artar. Parazit ile kronik olarak enfekte olan immunkompromize annelerin bebekleri de konjenital toksoplazmozun ekarte edilmesi açısından detaylı bir şekilde incelenmelidir. Böyle yenidoğanlarda tam kan, serebrospinal sivi ve idrarda PZR da tanıda başarıyla kullanılmıştır. Toksoplazmozun tanısında 2000 yilından itibaren gerçek zamanlı PZR da kullanılmaktadır (38). Amplifikasyon

\section{KAYNAKLAR}

1. Dubey JP. Toxoplasmosis. In: Cox FEG, Kreier JP, Wakelin D, editors. Topley \& Wilson's Microbiology and Microbial Infections. Vol.5 Parasitology Vol. 9th ed. Arnold Press; 1998. p.303-318.

2. Kim K, Weiss LM. Toxoplasma gondii: the model apicomplexan. Int J Parasitol 2004;34:423-432.

3. Dubey JP, Lindsay DS, Speer CA. Structures of Toxoplasma gondii tachyzoits, bradyzoits, and sporozoites and biology and development of tissue cysts. Clin Microbiol Rev 1998;11:267-299.

4. Sibley LD, Boothroyd JC. Virulent strains of Toxoplasma gondii comprise a single clonal lineage. Nature 1982;359:82-85.

5. Cook AJ, Gilbert RE, Holland FJ et al. Sources of Toxoplasma infection in pregnant women: European multicenter casecontrol study. European Research Network on Congenital Toxoplasmosis. Br Med J 2000;321:142-147.

6. Altıntaş N, Yolasığmaz A, Yazar S, ve ark. İzmir ve çevresindeki yerleşim bölgelerinde yaşayan insanlarda Toxoplasma antikorlarının araştırılması. Türkiye Parazitol Derg 1998;21:245-247.

7. Davaro RF, Thirumalai A. Life-threatening complications of HIV infection. J Intensive Care Med 2007;22:73-81. ve ürün saptanmasını birleştiren bir yöntemdir. Floresan ile işaretli oligonükleotid prob kullanılarak PZR sonrası işlemler ortadan kaldırılmıştır. DNA ekstraksiyon yöntemleri de otomatize hale gelmiştir. Santirifüj, vakum pompası veya yüksek kontaminasyon riski taşıyan diğer adımlar olmaksızın, manyetik bilye tekniği kullanılarak, çeşitli klinik örneklerden DNA saflaştırılmaktadır. Gerçek zamanlı PZR ve otomatize DNA ekstraksiyon yöntemlerinin kullanılması, laboratuvarlar arası değişkenliği azaltacaktır. Gerçek zamanlı PZR'nda kantitasyon da yapilabilmesi fötal prognoz açısından klinisyene yol gösterilebilmektedir.

8. Campbell AL, Goldberg CL, Magid MS et al. First case of toxoplasmosis following small bowel transplantation and systematic review of tissue-invasive toxoplasmosis following noncardiac solid organ transplantation. Transplantation 2006; 81:408-17

9. Dodds EM. Toxoplasmosis. Curr Opin Ophthalmol 2006;17:557-61.

10. Petersen E. Toxoplasmosis. Seminars in $\mathrm{Fe}-$ tal and Neonatal Medicine 2007;12:214223.

11. Kaul R, Chen P, Binder SR. Detection of Immunoglobulin $M$ antibodies specific for Toxoplasma gondii with increased selectivity for recently aquired infections. J Clin Microbiol 2004;42:5705-5709.

12. Svobodova V, Literak I. Prevalence of IgM and IgG antibodies to Toxoplasma gondii in blood donors in Czech Republic. Eur J Epidemiol 1998;14:803-805.

13. Jones J, Lopez A, Wilson M. Congenital toxoplasmosis. Am Fam Physician 2003;67:2131-2138.

14. Meeting report. The VIIIth International Congress on Toxoplasmosis. Microb Infect 2006;8:1979-1983.

15. Montoya JG. Diagnosis of Toxoplasma gondii infection and toxoplasmosis. J Infect Dis 2002;185(Suppl1):S73-82.
Toksoplazmoz, T.C. Sağlık Bakanl1ğı' nın "Bulaşıcı Hastalıkların İhbarı ve Bildirim Sistemi; Standart Tanı, Sürveyans ve Laboratuvar Rehberi"ne göre, bildirimi zorunlu hastalıklar C grubunda yer almaktadır (39). Bu rehberde, tanı yöntemleri ve kesin tanı kriterleri tarif edilmiştir. Şu anda piyasada bulunan pekçok ticari kitin kalite kontrol, duyarlılık ve özgüllük açısından eksikliklerinin olması, sonuçlar ve sonuçların yorumlanmasında anlaşmazlıklara yol açmakta, hem laboratuvarların klinisyenleri hem de klinisyenlerin hastaları yanlış bilgilendirmesine neden olmaktadır. Toksoplazmoz tanısında kullanilan metodun güvenilirliği, testi uygulayan laboratuvarın güvenilirliği ve klinik duruma göre sonuçların doğru yorumlanabilmesine bağlıdır.

16. Garcia LS. Protozoa from other sites. Diagnostic Medical Parasitology. 5th ed. Washington, D.C.:ASM Press; 2007. p.123-141.

17. Reiter-Owona I, Petersen E, Joynson D, et al. The past and present role of SabinFeldman dye test in the serodiagnosis of toxoplasmosis. Bull World Health Organ 1999;77:929-935.

18. Rigsby P, Rijpkema S, Guy EC, Francis J, Das RG. Evaluation of candidate international standard preparation for human anti-Toxoplasma immunoglobulin G. J Clin Microbiol 2004;42:5133-5138.

19. Meek B, Gool TV, Gilis H, Peek R. Dissecting the IgM response during the acute and latent phase of toxoplasmosis. Diagn Microbiol Infect Dis 2001;41:131-137.

20. Ashburn D, Joss AW, Pennington TH, Ho-Yen DO. Do IgA, IgE and IgG avidity tests have any value in the diagnosis of Toxoplasma infection in pregnancy? J Clin Pathol 1998;51:312-315.

21. Wong S, Hadju M, Ramirez R, Thulliez P, McLeod R, Remington JS. Role of specific immunoglobulin $\mathrm{E}$ in diagnosis of acute Toxoplasma infection and toxoplasmosis. J Clin Microbiol 1993;31:2952-2959.

22. Sabin AB, Feldman HA. Dyes as microchemical indicators of a new immunity phenomenon affecting a protozoan para- 
site (Toxoplasma). Science 1948;108:660663.

23. Danneman B, Vaughn W, Thulliez P, Remington JS. Differential agglutination test for diagnosis of recently acquired infection with Toxoplasma gondii. J Clin Microbiol 1990;28:1928-1933.

24. Naot Y, Remington J. An enzyme-linked immunosorbent assay for detection of IgM antibodies to Toxoplasma gondii : use for diagnosis of acute acquired toxoplasmosis. J Infect Dis 1980;142:757-766.

25. Desmonts G, Naot Y, Remington JS. Immunoglobulin $\mathrm{M}$ immunosorbent agglutination assay for diagnosis of acute congenital and acquired Toxoplasma infections. J Clin Microbiol 1981;14:486491.

26. Hedman K, Lappalainen M, Seppala I, et al. Recent primary Toxoplasma infection indicated by a low avidity of specific IgG. J Infect Dis 1989;159:736-739.

27. Montoya JG, Huffman HB, Remington JS. Evaluation of the immunoglobulin $\mathrm{G}$ test for the diagnosis of toxoplasmic lymphadenopathy. J Clin Microbiol 2004; 42:4627-4631.

28. Lappalainen M, Hedman K. Serodiagnosis of toxoplasmosis. The impact of measure- ment of IgG avidity. Ann Ist Super Sanita 2004; $40: 81-88$

29. Liesenfeld O, Montoya JG, Kinney S, et al. Effect of testing for IgG avidity in the diagnosis of Toxoplasma gondii infection in pregnant women: experience in a US reference laboratory. J Infect Dis 2001;183:1248-1253.

30. Wilson M, Remington JS, Clavet C, et al. Evaluation of six commercial kits for detection of human immunoglobulin $\mathrm{M}$ antibodies to Toxoplasma gondii. J Clin Microbiol 1997;35:3112-3115.

31. Remington JS, Thulliez P, Montoya JG. Recent development for diagnosis of toxoplasmosis. J Clin Microbiol 2004;42:941945.

32. Remington JS, Araujo FG, Desmonts G. Recognition of different Toxoplasma antigensby IgG and IgM antibodies in mothers and their congenitally infected newborns. J Infect Dis 1985;152:1020-1024.

33. Liesenfeld O, Montoya JG, Tathineni NJ, et al. Confirmatory serologic testing for acute toxoplasmosis and rate of induced abortions among women reported to have positive Toxoplasma immunoglobulin $\mathrm{M}$ antibody titers. Am J Obstet Gynecol 2001;184:140-145.
34. Reiter-Owona I. Laboratory diagnosis of toxoplasmosis-possibilities and limitations. J Lab Med 2005;29:439-445.

35. Chabbert E, Lachaud L, Crobu L, et al. Comparison of two widely used PCR primer systems for detection of Toxoplasma in amniotic fluid, blood and tissues. J Clin Microbiol 2004;42:1719-1722.

36. Filisetti D, Gorcii M, Pernot-Marino E, et al. Diagnosis of congenital toxoplasmosis: comparison of targets for detection of Toxoplasma gondii by PCR. J Clin Microbiol 2003;41:4826-4828.

37. Hohlfeld P, Daffos F, Costa JM, et al. Prenatal diagnosis of congenital toxoplasmosis with PCR test on amniotic fluid. N Engl J Med 1994;331:695-699.

38. Costa JM, Pautas P, Ernault F, et al. Real time PCR for diagnosis and follow up of toxoplasma reactivation after allogeneic stem cell transplantation using fluorescence resonance energy transfer hybridization probes. J Clin Microbiol 2000;38:2929-2932.

39. Bulașıcı hastalıkların ihbarı ve bildirim sistemi, Standart tanı, sürveyans ve laboratuvar rehberi. 4th ed. Ankara; 2005. p.115-116, p.249-250. 